\title{
Geçmişten Bugüne Türkiye'de Beslenme Plan, Program ve Politikaların Değerlendirilmesi ve Gelecek İçin Öneriler
}

\author{
Evaluation of Nutrition Plans, Programs, and Policies of Turkey and Recommendations for the \\ Future
}

\author{
Z. Begüm Kalyoncu Atasoy ${ }^{1}$, Dilek Aslan², Şeniz Ilgaz ${ }^{3}$, Türkan Kutluay Merdol ${ }^{4}$
}

Geliş tarihi/Received: 29.05.2021 • Kabul tarihi/Accepted: 07.12.2021

\section{ÖZET}

Beslenme ile ilgili eşitsizliklerin giderilmesinde, politika yaklaşımları en etkili ve maliyet etkinliği yüksek nüfus temelli araçlar olduğu için, beslenmeye bağlı halk sağllğı problemleri olan Türkiye gibi ülkeler, bireyi ve toplumu bir arada bütüncül ve kapsayıcı çevre odaklı beslenme politikalardan daha fazla istifade edecektir. Gelecek vadeden politika araçlarından olan mevzuat düzenlemelerinin güncellenmesi, eğitim/rehber oluşturma, vergilendirme gibi ekonomik stratejiler, besin zenginleştirmesi ve örselenebilir gruplara yönelik gıda yardımı sağlama süreçlerinin, Türkiye'deki gıda sistemini daha besleyici, sürdürülebilir, adil ve güvenli hale getirmek için, daha etkin kullanılmasını gerektirmektedir. Bu makalenin amacı; Türkiye’nin beslenme ile ilişkili politikalarını derlemek, analiz etmek ve ülkeye özgü öneriler sunmaktır. Beslenme ile ilişkili halk sağlığı politika analizinin odaklandığı temel konular ve bileşenleri; yaşam sürecindeki dönemlere göre programlar, özel dönem ve gruplara göre programlar, yeterli, dengeli ve sağlıklı beslenmeye yönelik genel programlar, risklerin önlenmesine yönelik özel programlar, eğitim programları ve izleme ve değerlendirme çalışmalarıdır.

Anahtar kelimeler: Beslenme politikaları, Türkiye

\begin{abstract}
Since, policy approaches are one of the most efficient and cost-effective population-based means of addressing the diet related disparities, Turkey, a country with diet related public health problems, would benefit from holistic and inclusive environment-oriented nutrition policies that combine the individual and the society. Promising policy tools such as regular legislation updates, education/guidance programs, fiscal measures such as taxation, fortification, and nutrition assistance programs for vulnerable groups could be used more effectively to make the food system to be more nutritious, sustainable, just, and safe for everyone in Turkey. Therefore, the aim of this paper is to review, analyze, and evaluate the current nutrition policies of Turkey along with providing country-specific recommendations. The nutrition related public health policy analysis was mostly concentrated on the issues and constituents including life course programs, programs for special cases and vulnerable groups, general programs for adequate balanced end healthy nutrition, specific programs for risk prevention, educational programs, and surveillance and evaluation of programs.
\end{abstract}

Keywords: Nutrition policies, Turkey

Çalışma daha önce 3. Uluslararası Sağılı Bilimleri Kongresi’nde poster olarak sunulmuştur.

1. İletişim/Correspondence: İstanbul Aydın Üniversitesi, Sağlık Bilimleri Fakültesi, Beslenme ve Diyetetik Bölümü, İstanbul, Türkiye

E-posta: begum.kalyoncu@atilim.edu.tr • — https://orcid.org/0000-0001-6208-3540

2. Hacettepe Üniversitesi, Tip Fakültesi, Halk Sağlığı Ana Bilim Dalı, Ankara, Türkiye • (ㄱ) https://orcid.org/0000-0002-4053-2517
3. Sağlık Bakanlığı Halk Sağlığı Genel Müdürlüğü, Ankara, Türkiye • ๑ https://orcid. org/0000-0003-0840-7617

4. Hacettepe Üniversitesi Sağlık Bilimleri Fakültesi, Beslenme ve Diyetetik Bölümü, Emekli Öğretim Üyesi, Ankara, Türkiye • • ㄴ https://orcid.org/0000-0002-0783-947X 


\section{GíRIŞ}

Beslenme, temelde yaşam sürecinde her türlü fiziksel ve zihinsel aktivite için gerekli enerji ve besin ögelerinin besinler yoluyla vücuda alınması, sindirimini, emilimini ve metabolizmasinı inceleyen bir bilim dalıdır (1). İnsanın büyüme ve gelişmesi, sağlıklı, üretken ve nitelikli bir yaşam sürmesi için yeterli, dengeli ve sağlıklı (YDS) beslenmesi gerekmektedir. Dünyada ve Türkiye'deki ölüm nedenleri arasında YDS beslenememenin rolü giderek artmakta ve beslenme ile ilgili risk faktörleri günümüzde hem gelişmiş hem de gelişmekte olan ülkeler için bulaşıcı olmayan hastalık yükünü artırarak ciddi bir halk sağlığı sorunu oluşturmaktadır. Çeşitli kalıtsal faktörler bulaşıcı olmayan hastalıklara zemin hazırlasa da beslenme ve yaşam tarzı gibi çevresel faktörlerin hastalık gelişiminde çok daha önemli olduğu bilinmektedir (2).

Gıda yetersizliği, gıda güvenliği ve güvencesi sorunlarına ek olarak aşırı kiloluluk, sağlıksız beslenme ve hareketsiz yaşam, büyük oranda önlenebilir olduğu için bu sorunların yönetimi beslenme ile ilgili bulaşıcı olmayan hastalıkların önlenmesi ve kontrolü konusunda imkânlar sunmaktadır. Buna rağmen, kalp hastalığı, obezite, diyabet gibi bulaşıcı olmayan hastalıkların "endişe verici” yaygınlığı, bireyler üzerinde gelir, öğrenim durumu, toplumsal cinsiyet gibi faktörler ile ilişkili olarak eşit olmayan yüklere sahiptir (3). Dolayısıyla, sağlığın sosyal belirleyicileri ve eşitsizlikler temelinde beslenme kaynaklı sorunlarla mücadele aynı zamanda toplumlar için ekonomik yükü de azaltmaya katkı sağlayabilecektir $(4,5)$.

Dünya Sağlık Örgütü (DSÖ) tarafından 1948 yılından bu yana kabul edilmiş olan "sağllk" hedefine erişebilmek için YDS beslenme bir koşuldur. $\mathrm{Bu}$ koşulun sağlanması da ulusal ve uluslararası sağlık ve beslenme politikalarının zamanında, doğru, kararlı ve sürdürülebilir olarak uygulanmasıyla başarılabilir (4). Beslenme ile ilgili plan ve programların oluşturulmasında en sık olarak kullanılan politika araçları; mevzuat düzenlemelerinin oluşturulması ve güncellenmesi, rehberlerin oluşturulması, eğitim ve farkındalık çalışmaları, sübvansiyon ve vergilendirme gibi mali önlemler, gıda zenginleştirmesi ve örselenebilir gruplara yönelik gıda yardımı sağlanması süreçleridir (5).

Bu sebeple, halk sağlığı beslenmesi ile ilgili yapılan bilimsel araştırmaların, makro düzeyde YDS beslenme ile ilgili kanunları, yönetmelikleri, düzenlemeleri vb. yasal kararlar ve standartları iyileştirici nitelik taşıması gerekmektedir (5).

Beslenme ile ilişkili politikalar hakkında çizilen çerçeve ile beraber bu makalenin amacı, Türkiye'nin beslenme plan, program ve politikalarının tarihsel süreci de kapsayacak şekilde değerlendirilmesi ve mevcut durum analizinden yararlanarak geleceğe dair önerilerin geliştirilmesidir. Değerlendirmeler kapsamında Türkiye'de beslenme durumuna etki edebilecekpolitikalar; sağlık etkileri, sürdürülebilirlik, eşitlik (equality) ve hakkaniyet (equity) kavramları dikkate alınmıştır.

\section{Küresel Düzeyde Değerlendirmeler}

Küresel düzeyde ortaya konulan beslenme politikalarl; herkesin eşit bir şekilde yeterli, dengeli ve sağlıklı (YDS) beslenme için gıdaya erişimini işaret eden gıda güvencesi ve gıda güvenliği gibi programlar kapsamında, okul çağı çocukları, gebeler, yaşlılar gibi riskli gruplara özel uygulamaları, bulaşıcı olmayan hastalıkların önlenmesi amacıyla tuz tüketiminin azaltılması, okul kantinlerinin denetlenmesi, ayaküstü beslenme seçeneklerinden uzak durulması ve trans yağ asitleri kullanımının eliminasyonu gibi konuları içerir (6).

Küresel beslenme politikaları açısından en güncel dokümanlardan birisi Birleşmiş Milletler Sürdürülebilir Kalkınma Amaçları'dır (7). Mevcut 17 amaç içindeki hedeflerin çoğunluğunun YDS beslenme ile ilişkili olduğu dikkati çekmektedir. Özellikle konusu "sıfır açlık" olan 'Amaç 2' besin üretim ve dağıtım konularına odaklanmaktadır. 
$\mathrm{Bu}$ 'Amaç' kapsamında dünyada yetersiz beslenme sorunu yaşayan 815 milyon kişinin sorunlarına çözüm(ler) üzerinde öneriler yer almaktadır (8). Fakat, 2019 Aralık ayından beri küresel yayılım göstererek milyonlarca insanın hastalanması ve ölmesiyle sonuçlanan Yeni Koronavirüs Hastalığı (COVID19)'un, 2030 sonuna kadar ulaşılması beklenen "sıfır açlık” amacının gerçekleştirilmesini imkânsız hale getireceği düşünülmektedir. Buna ek olarak, Birleşmiş Milletler Dünya Gıda Programı'na göre 2030 yılında yetersiz beslenen kişi sayısının daha da artarak 840 milyon kişiye yükseleceği tahmin edilmektedir (8).

Dünyada var olan dengesiz beslenme sorunlarına ilişkin tespit ve çözümler ise "Amaç 3; Sağlık ve iyilik” başta olmak üzere farklı amaçlar arasında yer almıştır. Amaç 1; Yoksulluğun olmaması, Amaç 6; Temiz su ve sanitasyon, Amaç 10; Eşitsizliklerin azaltılması, Amaç 13; İklim ile ilgili eylemler de beslenme konuları ile yakından ilişkilidir (7).

Küresel politikaların varlığı yerel uygulamalar için son derece önemlidir. Bu süreçlerin en önemli destekleyicileri arasında bilimsel kanıtların üretilmesi olduğu unutulmamalıdır. Dolayısıyla kanıta dayalı yaklaşımların geliştirilmesi ve yerel düzeylerde uygulanması mevcut akılcı politikaların var olması kadar önemlidir. $\mathrm{Bu}$ konuda son dönemlerde verilebilecek örneklerden birisi bulaşıcı olmayan hastalıklar arasında yer alan kalp ve damar hastalıklarından korunmak amacıyla oluşturulan “tuz tüketiminin azaltılması” politikasıdır. Bu politika ile tuz tüketimiyle ilişkili başta hipertansiyon olmak üzere bulaşıcı olmayan hastalıklarla toplumsal düzeyde mücadele amaçlanmaktadır. Dünya Sağlık Örgütü 2025 yllına kadar küresel tuz tüketimini \%30 oranında azaltma hedefiyle her yll 2.5 milyon ölümü önleyebilmeyi amaçlamaktadır (9).

Küresel hedefler arasında olan gıda güvenliği çok farklı nedenlere bağlı olarak gelişmektedir (10). Bu nedenler arasında iklim değişikliği yer almaktadır. Dünya Sağlık Örgütü, iklim değişikliğinin bakteri, virüs, parazit, toksik vb. ajanların gıda kontaminasyonunu artırdığı ve sağlık açısından tehdit oluşturduğuna işaret etmektedir (11). Birleşmiş Milletler Sürdürülebilir Kalkınma Amaçları arasında yer alan iklim konulu eylemler (Amaç 13) kapsamında gıda ile ilgili konulan ayrıntıların gıda güvenliğinin sağlanması açısından yeterli olmadığı düşünülmektedir (7).

Beslenme ile ilgili hedeflerin bütüncül ve kapsayıcı olması gerekmektedir. Dolayısıyla tekil politikalar kendi başına yararlı olsa bile, toplumsal ve uzun erimli YDS beslenme amaçları için geliştirilecek politika ve eylemlerin de sağlığın bütüncül ve kapsayıcı tanımı içinde ele alınmasının yararlı olacağı belirtilmektedir (6).

Beslenme ile ilgili değerlendirmeler yapılırken bazı kriterlerin kullanılması küresel durumun zaman içinde değişiminin/gelişiminin değerlendirilmesi, ülkelerin standart bir veri tabanı üzerinden karşılaştırılması gibi kolaylıklar sağlayabilir. $\mathrm{Bu}$ bağlamda öne çıkan bazı ölçütler doğrudan beslenme durumunu gösterdiği gibi beslenmeyi etkileyen koşullara ilişkin ölçütler de sürecin aktörlerini anlamaya yardımcı olabilir. Örneğin bir toplumda/ bölgede/ülkede zayıflı, bodurluk, kavrukluk gibi yetersiz beslenme ve fazla kiloluluk ya da obezite gibi dengesiz beslenme ölçütleri durumu ortaya koyar. Makro ve/veya mikro besin ögesi eksiklikleri, güvenli olmayan gıdaya bağlı meydana gelen hastalık ve ölümler, beslenme ile doğrudan ilişkili hastalık yüzdeleri bu başlıkta düşünülebilecek diğer ölçütlerdir. Beslenme durumu ve etkileyebilecek ilgili sağlık sorunlarının oluşmasına neden olan sosyoekonomik koşullar, iklim değişiklikleri, sağlıklı gıdaya erişimi engelleyen durumlarla ilgili ölçütler de metnin ilk bölümlerinde ifade edilen geniş bakış açısını içeren değerlendirmeye katkı sağlayabilecektir. Örneğin; dünyada beş yaş altı çocuklar arasında bodurluk yüzdesi 21.3 (12) ve bu değerin aslında bir sonuç olduğunu; bu sonucu etkileyebilecek bazı koşullara ilişkin rakamları da yakından takip etmek gerektiğini unutmamak gerekir (Şekil 1). Dolayısıyla özellikle çözüm üretirken bu koşul ve durumların tek tek ya da eşzamanlı düzeltilmesinin gereği için sistematik yaklaşım ve yöntemlerin geliştirilmesi gerekmektedir. 


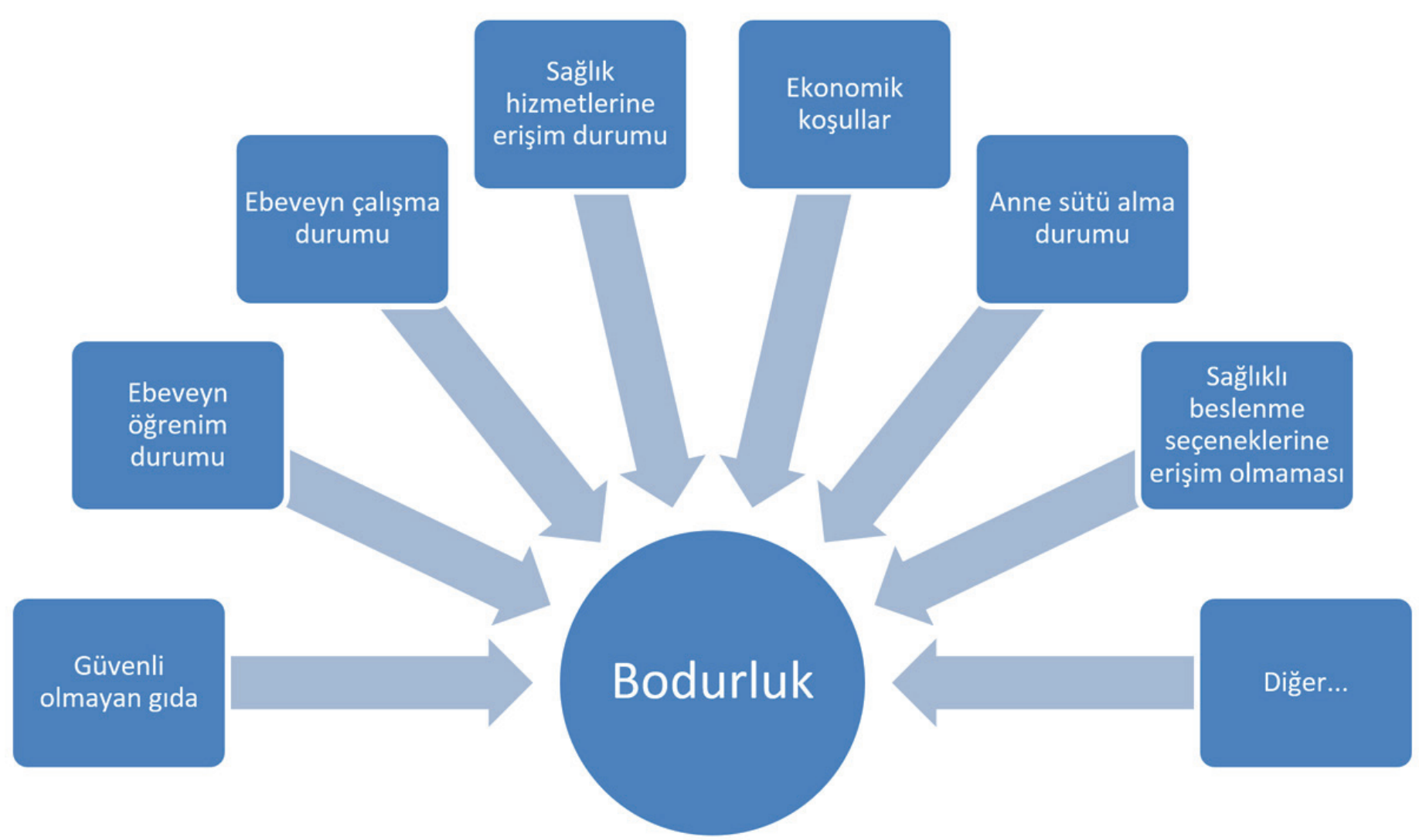

Şekil 1. Beş yaş altı çocuklarda bodurluğu etkileyen bazı faktörler (13)

\section{Beslenme Politikalarının Kısa Tarihçesi}

Beslenme politikası; beslenmenin temel ögesi olan besinin, üretimi, saklanması, işlenmesi, dağıtımı, yemek olarak hazırlanması, pişirilmesi ve servisi gibi tüm aşamaların belirli bir strateji içinde yürütülmesi için gereklidir $(14,15)$. Bu tanımlar çerçevesinde YDS beslenme için bir politika belirlenmesi, Sağlık Bakanlığı, gıda üretimi ile ilişkili bakanlıklar, Millî Eğitim Bakanlığı, Maliye Bakanlığı gibi pek çok bakanlığı ve Türk Standartları Enstitüsü, Türkiye İstatistik Kurumu Enstitüsü, Milli Prodüktivite Kurumu ve üniversiteler gibi pek çok kurumun iş birliğini gerektiren bir süreçtir. Beslenmenin bütün bu kapsamlı işlevine karşın, insanların M.Ö. 10.000 yıllarda yerleşik düzene geçmesinden itibaren başlayan; besin üretimi, besin alış-verişi, dağıtımı ve buna bağlı olarak toplumların birbiriyle savaşları sonrasında, bunun bir Dünya Savaşı’na dönüşmesi ile başlayan sürece kadar, beslenme politikası üzerine yazılı bir kaynak bulmak pek mümkün görünmemektedir (16). Nitekim Helsing (17), beslenme politikalarının, ilk olarak Birinci Dünya Savaşı’ndan sonra Paris’te gerçekleştirilen Barış Konferansı (Peace Conference-1919) sonrasinda, uluslararası anlaşmazlıkların çözümü için bir forum sağlamak üzere 1920'de kurulan Birleşmiş Milletler tarafından 1937 yılında gündeme alındığını bildirmektedir. Beslenme Politikaları, İkinci Dünya Savaşı’ndan sonra Birleşmiş Milletler bünyesinde kurulan Gıda ve Tarım Örgütü (Food and Agriculture Organization/FAO) ve Dünya Sağlık Örgütü (World Health Organization/ WHO) gibi oluşumları ile kapsamlı olarak ele alınmıştır (18). Bu gelişmeler paralelinde ilk olarak Amerika Birleşik Devletleri (ABD)'nde toplumda yetersiz besin alımına bağlı olarak gelişen büyüme ve gelişme gerilikleri, zayıflık, kansızlık ve benzeri pek çok hastalık için günlük beslenme düzenlerinde yapılabilecek değişikliklere yardımcı olacak personel gerekliliği gündeme gelmiş ve bu konularda yardımcı olacak kişilere diyetisyen unvanı verilmiştir (1899). ABD’de başlayan bu gelişme hızla ekonomisi gelişmiş ülkelerde yayılmış ve Avrupa ve Asya'da pek çok 
ülkede beslenme ve diyetetik alanında eleman yetiştirmek üzere üniversitelerde bölümler açılmaya başlamıştır (İlk ABD’de dört yıllık eğitim 1922 yılında). Türkiye'de bu eğitim 1962 yılında başlamıştır ki bu tarih dünya ülkeleri arasında oldukça iyi bir yere sahiptir (19).

Beslenme politikaları tarihçesinde bir diğer önemli tarih de 1950'li ylllardır. Her ne kadar İkinci Dünya Savaşı sonrasında diyabet, obezite, kalp hastalıkları ve kanser gibi bulaşıcı olmayan, kronik dejeneratif hastalıklar olarak sinıflanan hastalıklar ile beslenme arasındaki ilişki FAO ve WHO gibi yeni kurulan kurumların gündemine alınmışsa da bu konuda politikalar üretilmesi ancak 1950'lerden sonra başlamıştır. Bunun temel nedeni olarak; beslenme biliminin gelişim aşamalarında önceliğin besin ve besin ögesi yetersizliği nedeniyle oluşan hastalıklara verilmesi gösterilmektedir (20). Nishida ve arkadaşları (21) tarafindan hazırlanan ve DSÖ/FAO’nun 2012 yllında diyet, beslenme ve kronik dejeneratif hastalıklar konusunda yayınladığı bir raporda bu konu ayrıntılı bir şekilde değerlendirilmiştir.

\section{Türkiye'de Uygulanan Öncelikli Plan, Program ve Politikalara İlişkin Değerlendirmeler}

Türkiye'de gıda ve beslenme ile ilgili farklı dönemlerde uygulanan farklı politikaların haklı gerekçeleri anlaşılabilmektedir. Mevzuat, uygulama, izleme ve değerlendirme adımları tarihsel süreç içerisinde değişik ivmelerde sürdürülmüştür. Yazının bu bölümünde, günümüze yakın dönemde üretilen ve uygulamaya geçen gıda/beslenme politikalarının süreci etkileyen koşulların da gözetildiği bir bakış açısıyla değerlendirilmesi yapılmıştır.

Türkiye'de atılan adımlar genel olarak mevzuat ve rehber güncellemeleri, sık görülen sorunlarla baş etme yöntemi uygulamaları, tarım politikaları, eğitim ve farkındalık çalışmaları, çocuk, kadın, sığınmacı ve göçmen gibi toplumda sık etkilenen gruplara yönelik programlar, ekonomik politikalar öncelikli olmak üzere sürdürülmektedir (22). Tablo 1'de bu başlıklar ve başlıkları ilgilendiren bileşenler yer almaktadır.
Bebek, Çocuk ve Kadınlara yönelik programlar: 1991 yılından beri Sağlık Bakanlığı tarafindan emzirmenin devam ettirilmesi, teşvik edilmesi ve desteklenmesi için "Anne Sütünün Teşviki ve Bebek Dostu Sağlık Kuruluşları Programı” yürütülmektedir. $\mathrm{Bu}$ program kapsamında "bebeklerin doğumdan hemen sonra emzirmeye başlatılması, ilk 6 ay sadece anne sütü verilmesi ve 6 . aydan sonra uygun besinlerle beraber emzirmenin 2 yaşına kadar devam ettirilmesi” ve bu şekilde tüm bebeklerin yaşama sağlıklı başlamaları amaçlanmaktadır (23). Bebek Dostu Hastaneler programinin kapsamı genişletilmiş ve 2002 yılında "Bebek Dostu Aile Hekimliği” ve 2008 yılında da "Altın Bebek Dostu İl” uygulamalarına geçilmiştir. Altın Bebek Dostu Il kriterleri arasında il merkezinde bulunan tüm hastanelerin "Bebek Dostu Hastane” olması, ilçelerde bulunan doğum yapılan ya da çocuk hastanelerinin ve il genelindeki birinci basamak sağlık kuruluşlarının en az \%75’inin bebek dostu olmasının sağlanması bulunmaktadir (23). Emzirmenin korunması ve desteklenmesi ile programin temelini oluşturan 10 adımlı başarılı emzirme stratejisinin tüm sağlık kurum ve kuruluşlarında uygulanması ve devamının sağlanması ile çocuklarda morbidite ve mortalite hızlarının beslenme bozukluklarının önlenmesi yoluyla düşürülmesi hedeflenmektedir. Bu program kapsamında doğum yapılan sağlık kuruluşlarında, birinci basamak sağlık kuruluşları ve yeni doğan yoğun bakımlarında "emzirme danışmanlığı" uygulayıcı ve eğitici eğitimleri sağlanmaktadır. Ulusal değerlendirme ekipleri tarafindan değerlendirilen hastanelerin 80 ve üzerinde puan alanları üst komiteye sunularak, değerlendirme sonucunda "Bebek Dostu Unvanı” almaktadır (24).

Doğumdan iki yaşın sonuna kadar olan "kritik pencere dönemi" fiziksel ve davranışsal büyüme, gelişme ve yaşama sağlıklı başlangıç için önemli bir süreç olup çocukluk çağı hastalıklarının ve ölümün temel sebeplerinden olan büyüme geriliği, mikro besin ögesi eksiklikleri ve ishallerin en sık görülüğü dönemdir. Bu sebeple Sağlık Bakanlığı tarafindan “Tamamlayıcı Beslenme Programı” yürütülmektedir 
Tablo 1. Türkiye'de uygulanan besin ve YDS beslenmeye yönelik politika konuları, ilgili yürütücüler ve iş birliği yapılan kuruluşlar

\begin{tabular}{ll}
\hline Politika Temel Başlığı ve Konusu & $\begin{array}{l}\text { Politika ile İlgili Yürütücüler ve } \\
\text { İş Birliği Yapılan Kuruluşlar }\end{array}$ \\
\hline $\begin{array}{l}\text { Bebek, Çocuk ve Kadınlara yönelik programlar } \\
\text { Yeni doğan ve çocuk beslenmesi }\end{array}$ & SB, TOB, MEB, üniversiteler, STK’lar \\
Yetişkin beslenmesi, Kadın beslenmesi & SB, TOB, üniversiteler STK'lar
\end{tabular}

Gıda güvencesizliği, sığınmacılar ve göçmenlere yönelik programlar

Gıda güvencesi (erişim)

SB, TOB, TB, diğer bakanlıklar, yerel yönetimler, STK'lar

Sığınmacılar, göçmenler ve beslenme

YDS beslenme ve tarım politikalarına yönelik genel programlar:

Gida etiketleme

Tarım politikaları

Gıda takviyesi ve zenginleştirme

Gida pazarlaması

Okul programları

Sürdürebilir çevre

Risklerin önlenmesi, eğitim ve izlemeye yönelik programlar

Tuz tüketiminin azaltılması

Trans yağ asitleri ile ilgili politikalar

Gıda güvenliği

Farkındalık kampanyaları

Beslenmenin izlenmesi ve değerlendirilesi

Beslenme rehberi

MEB: Milli Eğitim Bakanlığı, SB: Sağlık Bakanlığı, TOB: Tarım ve Orman Bakanlığı, STK: Sivil Toplum Kuruluşu, TB: Ticaret Bakanlığı, ÖS: Özel sektör, RTÜK: Radyo ve Televizyon Üst Kurulu

ve sağlık personeline beslenme danışmanlık eğitimleri ile beraber anne sütü ve emzirme danışmanlı̆̆ı eğitimleri verilmektedir. Verilen eğitimlerle sağlık çalışanlarının annelerin ve bebeklerin özelliklerine ve ihtiyaçlarına özel danışmanlık verebilmeleri sağlanmaktadır. Program kapsamında hedef beş yaş altı çocuklarda akut ve kronik malnütrisyonun önlenmesidir (25).

Bunlara ek olarak; toplumun demir yetersizliği konusunda bilinçlendirilmesi, bebeklerin ilk altı ay anne sütü almasının ve altıncı aydan sonra uygun ve yeterli düzeyde ek besine geçirilerek, emzirmenin iki yaşına kadar sürdürülebilmesi amacıyla 2004 yılında "Demir Gibi Türkiye Programı” başlatılmıştır. Bu program kapsamında bebekleri ve çocukları demir yetersizliğinin olumsuz sağlık etkilerinden korumak için; 4-12 ay arası her bebeğe profilaktik olarak ücretsiz demir desteği ve 13-24 ay arasında anemi tanısı olan çocuklara demir tedavisi sağlanmaktadır (26,27).

Demir desteğine ek olarak Sağlık Bakanlığı D vitamini desteği de sağlamaktadır. Raşitizm her yaşta grubunda görülebilmekle beraber en sık olarak, D vitamini eksikliğine bağlı olarak süt çocukluğu döneminde görülmekte ve tedavi edilmezse 2-3 yaşından itibaren kemiklerde şekil bozukluklarına neden olmaktadır. Bu yüzden toplumun D vitamini yetersizliği konusunda bilinçlendirilmesi ve ülke çapında bebeklerin kemik gelişimini desteklemek amacıyla 2005 yllından itibaren bir yaş altındaki çocuklara günlük olarak 400 IU D vitamini desteği ücretsiz olarak verilmektedir (28). 
Son olarak; kadın ve üreme sağlığı hizmetleri çerçevesinde özellikle 15-49 yaş üreme çağındaki kadınlara yönelik Sağlık Bakanlığı'nın yürüttüğü çalışmalarda beslenmeyle ilgili önerileri de bulunmaktadır (29).

Gıda güvencesizliği, sığınmacılar ve göçmenlere yönelik programlar: Literatürde "gıda güvencesizliği”|“gıda yoksulluğu”/“açlık” olarak nitelendirilen yetersiz beslenme durumu yetişkinlerde ve özellikle çocuklarda fiziksel ve psikososyal sağlık sorunlarıyla ilişkilendirilmektedir (30). Gıda güvencesizliğinin insani boyutunun yanı sıra neden olduğu sağlık problemlerinden ötürü ekonomik bir boyutu da vardır. 2017 yılında yapılan Türkiye Beslenme ve Sağlık (TBSA) araştırmasının sonuçlarına göre ülke nüfusunun \%23.4'ünün son bir yıl içinde para ve diğer kaynakların yetersizliği nedeniyle yeterli gıda bulamama kaygısı taşıdığı, ekonomik zorluklar yüzünden \%16.5'inin gerekenden daha az besin tükettiği ve \%8.4'ünün de karnı aç olmasına rağmen yemek yiyemediği raporlanmıştır (31). Dünya Bankası'nın COVID-19 pandemisi öncesi ve sonrası Türkiye hakkında yayınladığı raporlar kıyaslandığında 2020 yılında Türk lirasının Amerikan doları karşısında \%20 değer kaybettiği, yoksulluğun anlamlı şekilde arttığı ve 2020 yılı sonunda 1.6 milyon insanın daha fakirlik sınırları altında yaşamaya başladığı tahmin edilmektedir (32). Veriler Türkiye'de yoksullukla mücadelede beslenme temelli sistematik ulusal programların ivedilikle geliştirilip uygulanması gerektiğini göstermektedir. Gıda güvencesi Tarım ve Orman Bakanlığı'nın Stratejik Planında hedef ve planları kapsamında yer almasına rağmen Türkiye'de hâlihazırda yoksullukla mücadele kapsaminda yürütülen programlar sistematik olmayıp; yerel yönetimler ve çeşitli sivil toplum dernekleri liderliğinde ilerlemektedir (33).

Bununla beraber Türkiye'de, düşük gelir düzeyine sahip sığınmacılar farklı kurumlardan gıda yardımı ve eğer kayıtlı olarak ikamet ediyorlarsa da belirli şartları taşımak kaydıyla sistematik nakdi yardım alabilmektedirler. Örneğin Türkiye'de kayıtlı bulunan sığınmacılar/mülteciler 2018 yılından beri nakit temelli bir destek programı olan ve Avrupa Birliği tarafindan fonlanan Kızılay Kart programindan faydalanabilmektedirler. Bu programdan yararlanan sığınmacı/mültecilere hane başına bir kart verilerek, hanede bulunan kişi başına aylık standart miktarda bir yardım sağlanmaktadır. Sağlanan yardımların miktarı ülkenin ekonomik koşullarına göre artırılmaktadır (34).

Sistematik yürüyen Kızllay Kart programına ek olarak sığınmacı/mülteci aileler büyükşehir belediyelerinin yardım programlarına başvurabilmekte, Halk ekmek yardımı alabilmekte ve çeşitli sivil toplum kuruluşlarından da yardım talep edebilmektedirler. Türkiye'de kayıt altında bulunan ve geçici kimlik numarası almış olan Suriye uyruklu bireyler acil sağlık, koruyucu ve temel sağlık hizmetleri ile tedavi edici tüm sağllk hizmetlerinden ücretsiz olarak faydalanabilmektedir.Geçicikimliknumarasıalmamış olanlara ise Geçici Koruma Yönetmeliği çerçevesinde, bulaşıcı hastalıklarla mücadele, bağışıklama ve acil sağlık hizmetleri sunulduğu belirtilmektedir. Ayrıca ülkemizde yaşayan Suriye'den göç etmiş kişilere yönelik koruyucu ve temel sağllk hizmetlerini daha etkin bir şekilde sunabilmek, dil ve kültür bariyerinden kaynaklanan sorunları aşabilmek, sağlık hizmetlerine erişimi artırabilmek için bu kişilerin yoğun olarak yaşadıkları yerlerde, ilçenin toplum sağlığı merkezi bağlı birimi olarak göçmen sağlığı merkezleri kurulmaktadır. Bu merkezlerde diyetisyenlerin görevlendirilerek, bu gruplara devlet tarafından beslenme konusunda danışmanlık hizmeti sağlanmaktadır (29).

YDS beslenmeye ve tarım politikalarına yönelik genel programlar: "Türkiye Sağlıklı Beslenme ve Hareketli Hayat Programı 2019-2023” ülkemizde beslenme alanında geliştirilen ve güncellenen önemli programlardandır. Bu program kapsamında Türkiye'de prevalansı artan obezite ile mücadele etmek, sağlığa yönelik çevresel risklerden bireyleri 
korumak ve sağlıklı yaşam tarzını teşvik ederek YDS beslenme ve hareketli hayat alışkanlıklarını kazandırmakvegeliştirmekamaçlanmaktadır.Türkiye Sağlıklı Beslenme ve Hareketli Hayat Programı"nın temel hedefi obezite ile ilişkili hastalıkların görülme sıklığının azaltılmasıdır. Ulusal ve yerel düzeyde politik istek ve kararlılığın sağlanması, koruyucu sağlık hizmetleri kapsamında toplumun bilinçlendirilmesi, gerekli mevzuat düzenlemelerinin ve iş birliklerinin yapılması, obezitenin teşhis ve tedavisine yönelik önlemlerin alınması ile izleme ve değerlendirme çalışmaları bu programın kapsamını oluşturmaktadır (28). Sağlık Bakanlığı tarafindan toplumun beslenme konusunda bilinçlendirilmesi amacıyla "Sağlıklı Beslenme ve Hareketli Hayat Programı”na ek olarak "Türkiye Aşırı Tuz Tüketiminin Azaltılması Programı” yürütülmektedir (28).

Bunların yanı sıra; YDS beslenmenin sağlanabilmesi için gıda etiketlerinin tüketiciyi en doğru şekilde yönlendirmesi gereklidir. 26 Ocak 2017 tarih ve 29960 (Mükerrer) sayılı Resmi Gazetede yayınlanan “Türk Gıda Kodeksi Gıda Etiketleme ve Tüketicileri Bilgilendirme Yönetmeliği” ne göre gıda etiketlerinde enerji değeri, yağ, doymuş yağ, karbonhidrat, şekerler, protein ve tuz miktarlarının bildirimi zorunlu hale getirilmiştir. Beslenme bildirimlerinde referans alım düzeylerinin gösterimi gönüllüdür (35).

Ayrıca, Tarım ve Orman Bakanlığı'nın stratejik planında; tarım politikaları ile ilgili stratejik hedef ve planlar belirlenmiştir. Buna göre; bitkisel ve hayvansal üretim ile su ürünleri üretiminin geliştirilmesi, tarım sektörünün geliştirilmesine ve tarım politikalarının oluşturulmasına yönelik araştırmalar yapılması, gıda üretimi, güvencesi ve güvenliği, kırsal kalkınma, toprak, su kaynakları ve biyoçeşitliliğin korunması, verimli kullanılmasının sağlanması, çiftçinin örgütlenmesi ve bilinçlendirilmesi öncelikli hedef ve planları bulunmaktadır (33). Benzer olarak, Çevre ve Şehircilik Bakanlığı'nın İklim Değişikliği Eylem Planı (2011-2023)'nın tarım sektörüne yönelik amaç ve hedefleri de mevcuttur (36).
Diğer taraftan, toplumdaki beslenme yetersizlikleri ile mücadelede gıda zenginleştirme yaklaşımı da uygulanmaktadır. Bu programlardan en önemlisi Türkiye'de 1994 yılından beri uygulanan "İyot Yetersizliği Hastalıklarının Önlenmesi ve Tuzun İyotlanması Programı"dır. Bu program sayesinde önlenebilir zekâ geriliğinin en önemli sebeplerinden olan iyot yetersizliğinin önlenmesi kapsamında yapılan eğitim, farkındalık, izleme ve denetimler ile Türkiye'de iyotlu tuz kullanımı anlamlı şekilde yükselmiştir. İyotlu tuz kullanım sıklığı 1995 yılında \%18.2 iken 2008 yılında yapılan Türkiye Nüfus Sağlık Araştırması'nda (TNSA) \%85.4 olduğu bulunmuştur. Ne yazık ki iyotlu tuz tüketimi 2013 ve 2018 yıllarında yapılan TNSA'larda sorulmamış olsa da; 2017 yılında yapılan TBSA'da bireylerin \%83.9'u iyotlu tuzu tercih ettiğini belirtmesine rağmen sofrada/tuzlukta kullanılan tuz çeşidi dağılımına bakıldığında iyotlu sofra tuzu kullanan bireylerin oranının \%66.5 olduğu bulunmuştur (31). İyotlu tuz tüketiminin yıllar içinde azalmış olması bu konuda yapılması gereken politika çalışmalarını bir öncelik haline getirmektedir. Türkiye'de birçok gıda yasal olarak zorunlu olmasa da üreticiler tarafindan iyotla zenginleştirilmekteyse de iyot alım durumunun izlemi için, gebe ve çocuklar gibi hassas gruplarda iyot alım düzeylerine bakılması önem arz etmektedir (37).

Bunlara ek olarak, 6112 sayılı Radyo ve Televizyonların Kuruluş ve Yayın Hizmetleri Hakkında Kanun'un "Yayın Hizmetlerinde Ticarî İletişim” başlıklı 9' uncu maddesinin yedinci fikrasinda yer alan "Genel beslenme diyetlerinde aşırı tüketimi tavsiye edilmeyen gida ve maddeler içeren yiyecek ve içeceklerin ticarî iletişimine, çocuk programlarıla birlikte veya bu programlarin içinde yer verilemez.” hükmünün uygulanmasında Sağlık Bakanlığı'nca hazırlanan “Gıda ve İçecek Listesi” temel alınmaktadır. Bu listeye göre çocuk programlarında çikolata, şeker, tatlı, gofret, enerji barı, tatlı sos, kek, kek karışımları, tatlı bisküvi, çikolata kaplı bisküvi, meyveli pay, cips, meyve suyu, enerji içeceği, alkolsüz şekerli ya da tatlandırıcılı içecek ve yenilebilir buz reklamlarına izin verilmemektedir (38). 
Son olarak, okullarda YDS beslenme ve hareketli yaşam konularında duyarlılığın artırılması ve okul sağlığının iyileştirilmesi için 2010 yılından itibaren "Beslenme Dostu Okul Projesi” Sağlık Bakanlığı ve Millî Eğitim Bakanlığı'nın beraber oluşturduğu bir protokol ile sürdürülmektedir. Okul kantinlerine yönelik olarak 2017’de Millî Eğitim Bakanlığı tarafından hazırlanan genelgeyle okul kantinlerinde bulundurulacak gıdalar için Sağlık Bakanlığı'nın hazırladığı “Okullara Yönelik Yiyecek ve İçecek Standartları” baz alınmaya başlanmıştır (29).

Risklerin önlenmesi, eğitim ve izlemeye yönelik programlar: Türkiye'de 1970 yllından beri toplumun beslenme konusunda bilinçlendirilmesi için Hacettepe Üniversitesi Beslenme ve Diyetetik Bölümü’nün Millî Eğitim Bakanlığı, Tarım Bakanlığı ve Sağlık Bakanlığı iş birliği ile öğretmenlere, sağlık çalışanlarına, mutfak yöneticileri ve personeline yönelik eğitim çalıştayları ve kursları düzenlenmektedir. O yıllarda başlayan bir diğer önemli eğitim faaliyetleri de radyo ve televizyonlardan verilen eğitim programlarıdır. Günümüzde de halkın beslenmede bilinçlendirilmesi ve eğitimi çalışmaları üniversitelerin Beslenme ve Diyetetik Bölümleri tarafindan yürütülmektedir. Risklerin önlenmesi konusundaki en önemli adım, Sağlık Bakanlığı tarafından 2010 yılından beri aşırı tuz tüketiminin azaltılmasına yönelik yürütülen program kapsamında, Tarım ve Orman Bakanlığı, üniversiteler, gıda sektörü ve sivil toplum kuruluşlarıyla (STK) yapılan iş birlikleri ile tuz tüketiminin azaltılmasının hedeflendiği programlardır. Bu kapsamda Türk Gıda Kodeksi'nin ilgili tebliğlerinde farklı gıdalarda tuz miktarı azaltılmış (ekmek, salça, zeytin, peynir, kırmızı pul biber, vb.), gıda sektörü ve toplu beslenme yapan yerlerde gönüllü tuz azaltma çalışmaları başlatılmış ve iş birliği protokolleri imzalanmıştır (29). Tuzun azaltılması programlarına ek olarak 2021 yılında T.C. Sağlık Bakanlığı Sağlıklı Beslenme ve Hareketli Hayat İşbirliği Platformu öncülüğünde Türkiye Şeker Tüketimini/Kullanımını Azaltma Rehberi yayınlanmıştır (29).
Ayrıca bulaşıcı olmayan hastalıklar açısından önemli bir halk sağlığı sorunu teşkil eden trans yağ asitleriyle ilgili olarak, Tarım ve Orman Bakanlığı 07 Mayıs 2020 tarihinde Türk Gıda Kodeksi Gıda Etiketleme ve Tüketicileri Bilgilendirme Yönetmeliği’nde değişiklik yaparak son tüketiciye sunulması amaçlanan gıdalarda ve perakende satışa yönelik gıdalardaki hayvansal yağlarda doğal olarak bulunan trans yağ asidi hariç gıdalarda trans yağ asidi içeriğini 100 gram yağda 2 gramı geçmeyecek şekilde düzenlemiştir. Tarım ve Orman Bakanlığı'nın ilgili mevzuatı ile "perakende işletmelere arz edilen gıdalar ile son tüketiciye sunulan gıdalarda trans yağ asidi miktarının toplam yağın 100 gramında 2 gramı geçmemesi” koşulu getirilmiştir. Bununla beraber, Tarım ve Orman Bakanlığı'nın Türk Gıda Kodeksi'nde yer alan "Gıdalara Vitaminler, Mineraller ve Belirli Diğer Öğelerin Eklenmesi Hakkında Yönetmelikte Değişiklik Yapılmasına Dair Yönetmelik” ile kısıtlanan trans yağ asidi miktarının ölçümüne dair standart bir metot belirlemesi ve üretilen gıdaların uygunluğunu denetlemesi gerekmektedir. Olumsuz sağlık etkileri bilimsel olarak kanıtlanmış endüstriyel trans yağ asitlerinin tüm gıda zincirinden kaldırılması amaçlanmalıdır (39).

Beslenme ile ilişkili vergi politikalarının oluşturulması kapsamında Sağlık Bakanlığı ile Hazine ve Maliye Bakanlığı iş birliği yapmaktadır (29). Bu konuda atılan en önemli adım 2018 yılında yapılan kanuni düzenlemeyle meyve nektarları, meyveli içecekler, limonatalar, enerji içecekleri, sporcu içecekleri, soğuk çay, soğuk kahve, tonik, tatlandırılmış veya aromalandırılmış benzeri içeceklere katma değer vergisine (KDV) ek olarak \%25 özel tüketim vergisi (ÖTV) konmasıdır. Mart 2021 yllında uygulanan ÖTV, \%25’ten \%35'e çıkarılmıştır. Bu uygulamanın, halk sağlığının geliştirilmesinde büyük öneme sahip olan alkolsüz ve şekerli içeceklerin tüketiminin sinırlandırılmasına katkı sağlayacağı düşünülmektedir. 
YDS Beslenme için yapılan eğitim ve izleme programları kapsamında, Sağlık Bakanlığı çeşitli farkındalık kampanyaları yürütmektedir (Şekil 2). Ayrıca Sağlık Bakanlığı beslenme ile ilgili kamu spotu ve afiş, broşür, kitapçık, vb. materyaller geliştirmekte ve bu materyalleri sağlık personeli ve toplumla paylaşarak eğitim faaliyetleri düzenlemektedir (28).
Türkiye'debeslenmeninizlenmesivedeğerlendirilmesi çalışmaları için öncelikli olarak toplum temelli araştırmalar kullanılmaktadır. Üniversitelerle iş birliğinde yapılan "Türkiye Beslenme ve Sağlık Araştırması, 2010 ve 2017, Çocukluk Çağı Obezite Araştırması 2013 ve 2016” gibi araştırmalar bunların başında yer almaktadır (29) (Şekil 3).

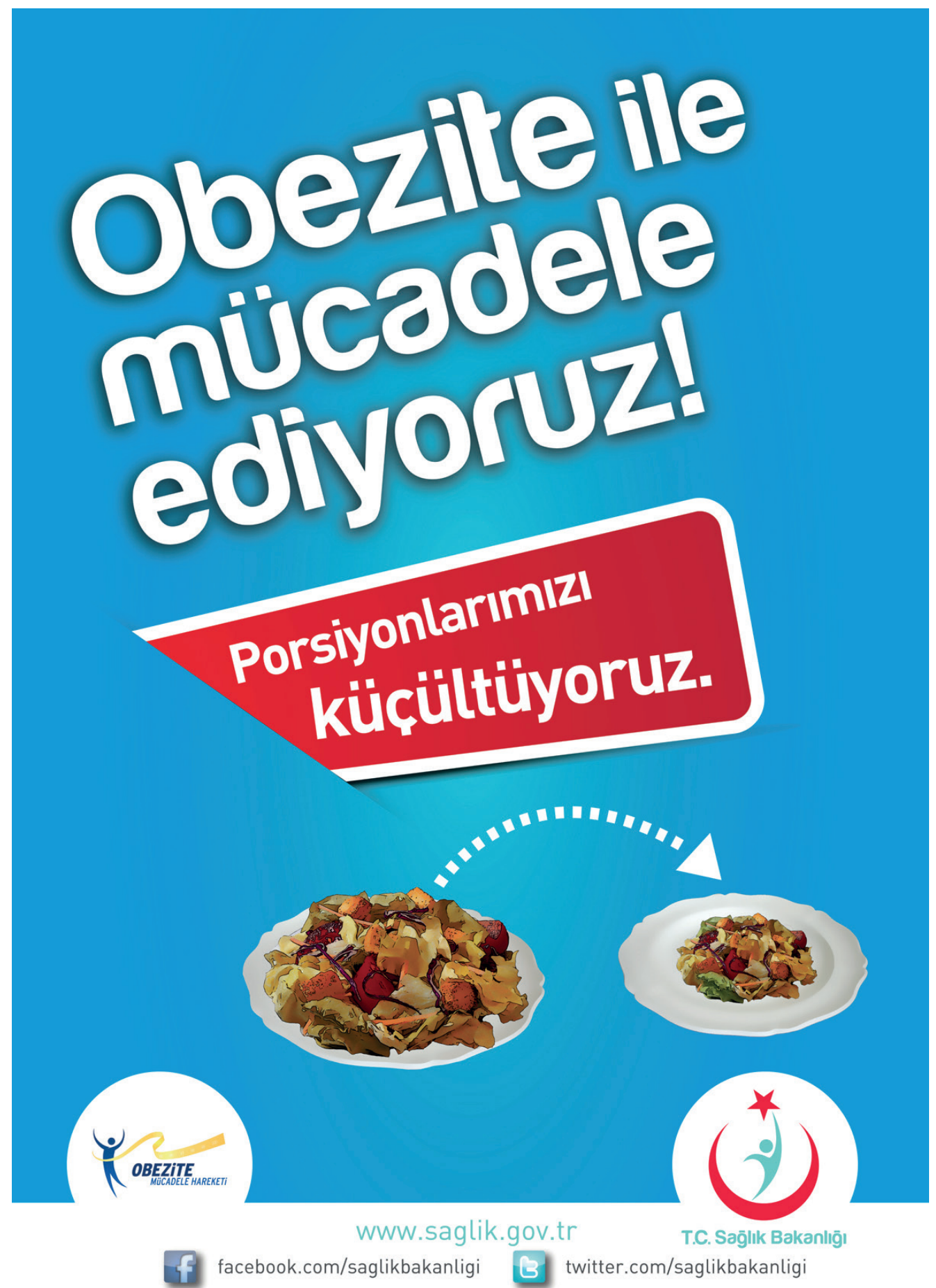

Şekil 2. “Obeziteyle Mücadele Ediyoruz” Kampanya Afişi (28) 


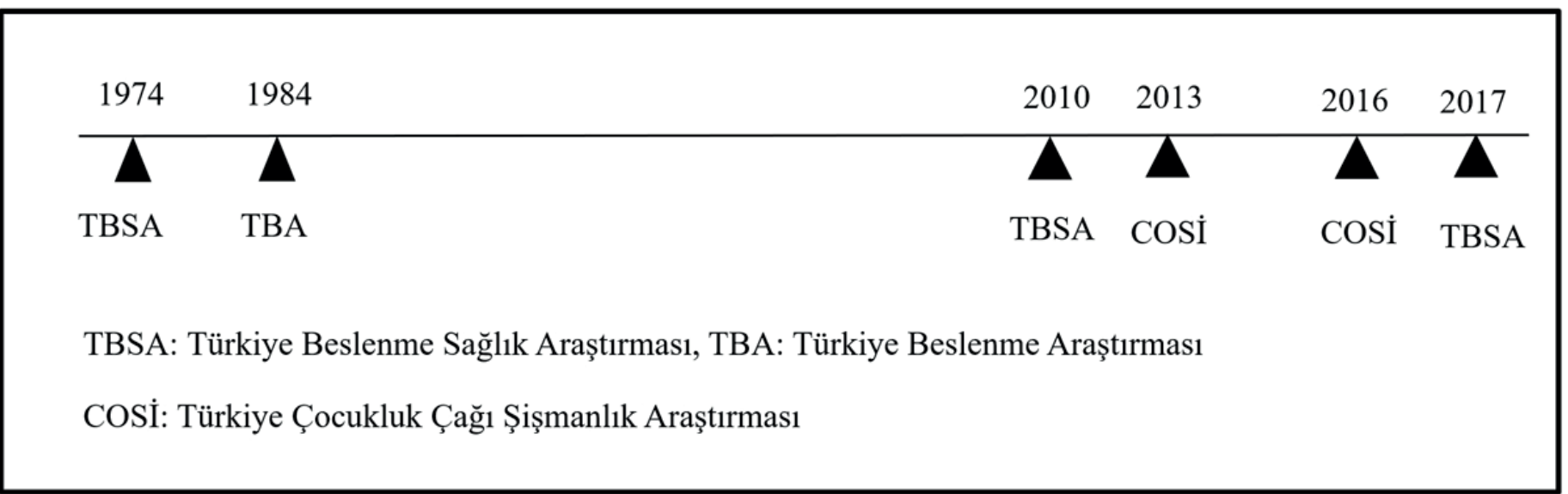

Şekil 3. Ülkemizde yapılan geniş kapsamlı beslenme araştırmalarının tarihçesi

$\mathrm{Bu}$ araştırmaların sonuçları baz alınarak Türkiye'de 2004 yllında Türkiye’ye Özgü Beslenme Rehberi, Devlet Planlama Teşkilatı ve Sağlık Bakanlığı görevlendirmesiyle Hacettepe Üniversitesi Beslenme ve Diyetetik Bölümü öncülüğünde yayınlanmış olup; bu rehber 2010 yılında saha araştırması yapılan TBSA sonuçları da baz alınarak, Sağlık Bakanlığı tarafından 2015 yılında Türkiye Beslenme Rehberi (TÜBER) ismiyle güncellenmiştir. Söz konusu Beslenme Rehberi; Besine Dayall Beslenme Rehberi, Besin Ögeleri ve Besin Grupları, Sağlıklı Vücut Ağırlığının Sağlanması ve Korunması, Tüketiminin Artırılması Gereken Besinler ve Besin Ögeleri, Tüketiminin Azaltılması Gereken Besinler ve Besin Ögeleri, Besin Güvenliği ve İlkeler bölümlerinden oluşmaktadır (40).

\section{SONUÇ VE ÖNERILER}

Geçmişten bugüne kadar farklı gerekçelerle farklı politikaların uygulanmasıyla Türkiye'de YDS beslenme hedefi gerçekleştirilmeye çalışılmıştır. Gelecek dönemde çalışmaların daha gerçekçi ve toplumun gereksinimine yönelik ve sürdürülebilir olması için halk sağlığı bakış açısıyla planlama ve uygulamaların yapılması gerekmektedir. Ayrıca beslenme ile ilgili uygulanan politikaların düzenli olarak değerlendirilmesi ve maliyet etkinlik analizlerinin yapılması gerekmektedir.

Türkiye'de güncel sorunları çözmeye yönelik olarak aşağıdaki başlıklarda ilerleme kaydedilmesi önerilmektedir:
1. Mevcut durum analizinin bilimsel yaklaşımlarla sürekli olarak yapılması, izleme ve değerlendirme çalışmaları,

a. Düzenli olarak beslenme, sağlık ve sosyal yaşam araştırmalarının kamu kaynakları ile yapılabilmesi ve bu verilerin halka açı erişimli sunulması,

i. Bilimsel ve teknik ekiplerin ilgili bütün bileşenlerin katkısı alınarak oluşturulması,

2. Bireylerin ve toplumun gida gereksinimlerine bütçe ayrılması,

3. Avrupa Gıda Güvenliği Otoritesi (EFSA) benzeri bağımsız yapıların kurulması ve uzun dönemde beslenme ve gıdaya özel ayrı bir bakanlığın kurulması,

4. Güçlü tarım ve çevre politikalarının uygulanması ve blok zincir yöntemlerle sürdürülebilirliğin sağlanması,

a. Kamuda beslenme odaklı daha fazla birimin kurulması, mevcut olanların güçlendirilmesi ve bu birimlerde diyetisyenlerin istihdam edilmesi,

5. Sektörler arası çalışmaların desteklenmesi ve sahiciliğinden ödün vermeyen sağlık dostu özel sektörün teşvik edilmesi,

6. Uluslararası iş birliklerinin desteklenmesi,

7. Sağlıksız yiyecek ve içeceklerin tüketimlerinin 
sinırlandırılmasının yanı sıra sağlıklı gıdaların tüketiminin sağlanabilmesi için politikaların uygulanması,

8. Bütün süreçlere toplum katılımının sağlanacağ modellerin oluşturulması,

a. Toplumda farkındalığın artırılması,

b. Medya aracılığı ile topluma verilen mesajlarda denetimin sağlanması.

c. Aile sağlı̆̆ merkezlerinde diyetisyen istihdaminin artırılması.

Sonuç olarak, beslenmeye yönelik çalışmalar temelde sağlığı ilgilendiren bir konu olduğundan farklı sektörlerin görev alanlarına giren bazı aktiviteleri içermekte ve bu aktiviteler farklı bileşenlerin iş birliğinde gerçekleştirilmektedir. $\mathrm{Bu}$ nedenle, kamunun ilgili bütün birimleri, meslek örgütleri, sivil toplum örgütleri, yerel yönetimler, toplumun kendisi gibi bütün bileşenleri kavrayan kısa, orta, uzun dönemli izlenebilir, geliştirilebilir (bütüncül ve kapsayıcı) politika ve yaklaşımlara ihtiyaç vardır. $\mathrm{Bu}$ bakış açısıyla, Türkiye'de beslenme temelli sorunların çözümünde başarının daha kalıcı olacağı düşünülmektedir.

Yazarlık katkısı - Author contributions: Tüm yazarlar makalenin yazımı ve revizyon sürecine katkı sağlamışlardır. - All the authors have contributed to the writing and revision processes of the article.

Çıkar çatışması - Conflict of interest: Yazarlar çıkar çatışması olmadığını beyan ederler. - The authors declare that they have no conflict of interest.

\section{KAYNAKLAR}

1. Kutluay Merdol T.Besin ögelerinin vücuttaki fonksiyonlarına genel bir bakış: yeterli, dengeli ve sağllklı beslenmenin temel özellikleri. Temel Beslenme ve Diyetetik (Ed. Kutluay Merdol T.) Güneş Tıp Kitabevleri, İstanbul, 2016.

2. Bahar Özvarış Ş, Aktuna G. Hacettepe Üniversitesi H. Bulaşıcı Olmayan Hastalıklardan Korunma. Merdiven Yayın. 2019. 5-6 [Available from: bulasiciolmayanhastaliklardankorunma.pdf (hacettepe. edu.tr) Erişim tarihi: 5 Aralık 2021.
3. Satia JA. Diet-related disparities: understanding the problem and accelerating solutions. Journal of the American Dietetic Association. 2009;109(4):610.

4. Mechlem K. Food security and the right to food in the discourse of the United Nations. European Law Journal. 2004;10(5):631-48.

5. Willett W. Nutritional epidemiology. 3rd ed. ed: Oxford University Press; 2013.

6. Mozaffarian DJNF. Dietary and policy priorities to reduce the global crises of obesity and diabetes. Nature Food. 2020;1(1):38-50.

7. United Nations. Sustainable Development Goals 2021 [Available from: https://www.un.org/ sustainabledevelopment/sustainable-developmentgoals/. Accessed December 05, 2021.

8. World Health Organization. The state of food security and nutrition in the world 2020: transforming food systems for affordable healthy diets: Food \& Agriculture Org.; 2020.

9. World Health Organization. Salt reduction 2020 [Available from: https://www.who.int/news-room/factsheets/detail/salt-reduction. Accessed December 05, 2021.

10. Fontannaz-Aujoulat F, Frost M, Schlundt JJFC. WHO Five Keys to Safer Food communication campaignEvidence-based simple messages with a global impact. 2019;101:53-11.

11. World Health Organization. Climate change and health 2018 [Available from: https://www.who.int/news-room/ fact-sheets/detail/climate-change-and-health. Accessed December 05, 2021.

12. World Health Organization. Child stunting 2019 [Available from: https://www.who.int/gho/childmalnutrition/stunting/en/. Accessed December 05, 2021.

13. Tariku A, Biks GA, Derso T, Wassie MM, Abebe SMJ. Stunting and its determinant factors among children aged 6-59 months in Ethiopia. Ital J Pediatr. 2017;43(1):19.

14. Pekcan G. Beslenme Sorunlarının Önlenmesi: Besin ve Beslenme Politikaları 2018 [Available from: https:// gtbd.org.tr/wp-content/uploads/2018/11/Prof.-Dr.G\%C3\%BClden-Pekcan.pdf. Erişim tarihi: 5 Aralık 2021.

15. Pekcan G. Food and nutrition policies: what's being done in Turkey. J Public Health Nutrition. 2006;9(1a):158-62.

16. Kutluay Merdol T. Beslenme Antropolojisi 1, 4. Basım, Hatiboğlu Yayınevi, Ankara. 2020.

17. Helsing E. The history of nutrition policy. J Nutrition Reviews. 1997;55(11):S1.

18. World Health Organization (WHO)/Food and Agriculture Organization (FAO). Policy Guidance Series 2021 [Available from: http://www.fao.org/publications/ policy-guidance-series/en/. Accessed December 05, 2021. 
19. Kutluay Merdol T. Beslenme ve Diyetetik: Tarihçe. Temel Beslenme ve Diyetetik (Ed. Kutluay Merdol T.) Güneş Tıp Kitabevleri, İstanbul, 2016.

20. World Health Organization. Food and nutrition policies and programmes list of publications 2021 [Available from: https://www.who.int/nutrition/publications/ policies/en/. Accessed December 05, 2021.

21. Nishida C, Uauy R, Kumanyika S, Shetty P. The joint WHO/FAO expert consultation on diet, nutrition and the prevention of chronic diseases: process, product and policy implications. Public Health Nutr. 2004;7(1a):24550.

22. Devlet Planlama Teşkilatı Müsteşarliğı İktisadi Sektörler ve Koordinasyon Genel Müdürlüğü. Ulusal Gida ve Beslenme Stratejisi Çalişma Grubu Raporu. Ankara, 2001.

23. T.C. Sağlık Bakanlığı Halk Sağlığı Genel Müdürlüğü. Anne sütünün teşviki ve bebek dostu sağlık kuruluşları programi. 2020;31.

24. T.C. Sağlık Bakanlığı Halk Sağllğı Konya İl Sağllk Müdürlügü. Altin Bebek Dostu İl Konya 2019 [Available from: https://konyaism.saglik.gov.tr/TR,153535/altinbebek-dostu-il-konya.html. Erişim tarihi: 5 Aralık 2021

25. Aktaç Ş, Garipağaoğlu M, Gökçay G, Akman Z. Çocuk sağlığı izlem polikliniğinde takip edilen dokuz ve on iki aylık bebeklerde tamamlayıcı beslenme uygulamaları ve besin ögesi alımlarının belirlenmesi. J Çocuk Dergisi. 2015;15(2):56-64.

26. Yalçın SS, Tezel B, Yurdakök K, Pekcan G, Özbaş S, Köksal E, Tunç B, Şahinli S, Altunsu AT, Köse MR, Buzgan T, Akdağ R. A community-based iron supplementation program, "Iron like Turkey", and the following prevalence of anemia among infants aged 12-23 months. The Turkish Journal of Pediatrics 2013;55:16-28. http://www.ncbi. nlm.nih.gov/pubmed/23692828

27. Gazi Üniversitesi Tıp Fakültesi. Türkiye'de 6-17 Aylık Çocuklarda ve Annelerinde Hemoglobin Ferritin D -Vitamini Düzeyi ve Demir Eksikliği Anemisi Durum Belirleme Yürütülen Programların Değerlendirilmesi Araştırması. Sağlık Bakanlığı Yayınları No: 873, Ankara,2011.

28. T.C. Sağlık Bakanlığı. Sağllğın Geliştirilmesi Genel Müdürlüğü Ana Sayfa 2021 [Available from: https:// sggm.saglik.gov.tr/. Erişim tarihi: 5 Aralık 2021.

29. T.C. Sağlık Bakanlığı Halk Sağlığı Genel Müdürlüğü. Sağlıklı Beslenme ve Hareketli Hayat Dairesi Başkanlığı
2021 [Available from: https://hsgm.saglik.gov.tr/tr/ beslenmehareket-anasayfa. Erişim tarihi: 5 Aralık 2021

30. Payne-Sturges DC, Tjaden A, Caldeira KM, Vincent KB, Arria AM. Student hunger on campus: food insecurity among college students and implications for academic institutions. Am J Health Promot. 2018;32(2):349-54.

31. T.C. Sağlık Bakanlığı Halk Sağlığı Genel Müdürlüğü. Türkiye Beslenme ve Sağlık Araştırması 2017. 2019. [Available from: https://hsgm.saglik.gov.tr/depo/ birimler/saglikli-beslenme-hareketli-hayat-db/Yayinlar/ kitaplar/TBSA_RAPOR_KITAP_20.08.pdf. Erişim tarihi: 5 Arallk 2021

32. The World Bank. The World Bank in Turkey 2021 [Available from: https://www.worldbank.org/en/ country/turkey/overview\#3. Accessed December 05, 2021.

33. Gıda Tarım ve Hayvancılık Bakanlığı. 2018-2022 Stratejik Plan. 2018. [Available from: https://www. tarimorman.gov.tr/SGB/Belgeler/2013-2017/GTHB\%20 2018-2022\%20STRATEJI\%CC\%87K\%20PLAN.PDF. Erişim tarihi: 5 Aralık 2021

34. Kızılay T. Sosyal Uyum (SUY) Programı 2021 [Available from: http://kizilaykart.org/. Erişim tarihi: 5 Aralık 2021.

35. Türk Gıda Kodeksi Gıda Etiketleme ve Tüketicileri Bilgilendirme Yönetmeliği. Resmi Gazete. 2017.

36. Çevre ve Şehircilik Bakanlığı. Türkiye Cumhuriyeti İklim Değişikliği Eylem Planı 2011-2023. 2011.

37. Ekşi A, Karadeniz F. Gıda zenginleştirme yaklaşımı ve Türkiye'de uygulanma olanağı. Beslenme ve Diyet Dergisi. 1996;25(2):47-51.

38. Radyo Televizyon Üst Kurulu. Aşırı Tüketimi Tavsiye Edilmeyen Gıda Maddelerinin Ticari İletişimine İlişkin Yeni Düzenleme 2018 [Available from: https://www. rtuk.gov.tr/duyurular/3788/5536/asiri-tuketimi-tavsiyeedilmeyen-gida-maddelerinin-ticari-iletisimine-iliskinyeni-duzenleme.html. Erişim tarihi: 5 Aralık 2021.

39. Türk Gıda Kodeksi Gıdalara Vitaminler, Mineraller ve Belirli Diğer Öğelerin Eklenmesi Hakkında Yönetmelikte Değişiklik Yapılmasına Dair Yönetmelik Resmi Gazete. 2020.

40. Türkiye Beslenme Rehberi TÜBER 2015, T.C. Sağllk Bakanlığı Yayın No: 1031, Ankara 2016. [Available from: https:/hsgm.saglik.gov.tr/depo/birimler/sagliklibeslenme-hareketli-hayat-db/Yayinlar/rehberler/2015beslenme-rehberi.pdf. Erişim tarihi: 5 Aralık 2021. 